\title{
MENULIS DAN STRES
}

\author{
WRITING AND STRESS
}

\author{
Fitrah Paradina \\ Program Studi Psikologi Fakultas Kedokteran Universitas Lambung Mangkurat \\ Jalan A. Yani KM 36.00, Banjarbaru, Kalimantan Selatan, 70714, Indonesia \\ E-mail :fitrahprd@gmail.com
}

\begin{abstract}
ABSTRAK
Menulis sebenarnya adalah suatu kegiatan yang mudah yang bisa dilakukan dimana saja dan kapan saja, menulis juga tidak harus selalu menggunakan media penyalur seperti kertas dan pulpen, ataupun tablet dan laptop, tetapi menulis juga bisa dilakukan dikepala kita melalui pikiran. Menulis adalah kegiatan yang menyenangkan karena dapat menuangkan perasaan yang sedang dirasakan. Selama pandemik Covid-19 ini mewabah di Indonesia, banyak orang yang merasakan stres dan bosan karena tidak dapat melakukan aktivitas seperti biasanya. Ketika perasaan stres datang kita bisa menyalurkan ataupun mengurangi stres tersebut salah satunya dengan menulis, ataupun mendengarkan musik. Menulis apa yang sedang dirasakan atau membuat rencana kegiatan yang akan dilakukan dapat membuat kita melupakan stres. Mendengarkan musik juga merupakan kegiatan yang sering dilakukan ketika mengalami stres, dengan mendengarkan musik perasaan yang disalurkan lewat lagu itu akan mengurangi sters yang dirasakan dan membuat kita menjadi happy kembali dan stres pun hilang. Satu hal yang sering terjadi ketika menulis adalah kesalahan dalam penulisan kata atau sering disebut dengan istilah typo, typo bisa terjadi dikarenakan adanya kecepatan kerja otak yang berpikir ketika sedang mengetik atau menulis, dan ketika ingin memperbaiki typo disaat tengah menulis itu bisa mengganggu kelancaran dalam menulis yang menyebabkan proses menyalin dari pikiran kedalaam tulisan digital menjadi berantakan. Kegiatan mendengarkan musik dan menulis merupakan salah satu kegiatan untuk menghilangkan stres yang bisa disebut dengan istilah coping stress yang tergolong dalam bagian escape avoidance.
\end{abstract}

Kata Kunci : Menulis, stres, typo

\begin{abstract}
Writing is actually an easy activity that can be done anywhere and anytime, writing also doesn't have to always use media such as paper and pens, or tablets and laptops, but writing can also be done in our heads through thoughts. Writing is a fun activity because it can express the feelings that are being felt. During the Covid-19 pandemic that broke out in Indonesia, many people felt stressed and bored because they could not carry out their usual activities. When feelings of stress come, we can channel or reduce stress, one of which is by writing, or listening to music. Writing down what you are feeling or making a plan for what to do can make us forget about stress. Listening to music is also an activity that is often done when experiencing stress, by listening to
\end{abstract}


feeling music that is channeled through the song will reduce the stress that is felt and make us happy again and stress is gone. One thing that often happens when writing is errors in writing words or often referred to as typos, typos can occur due to the speed at which the brain is thinking while typing or writing, and when you want to correct typos while writing it can interfere with the fluency of writing. causes the process of copying from the mind into digital writing a mess. Listening to music and writing activities is one of the activities to relieve stress which can be referred to as coping stress which is included in the escape avoidance section.

Keywords: Writing, stress, typo

Menulis, ketika saya mendengar kata menulis banyak yang terlintas dipikiran saya, bahwa menulis bisa kita lakukan dimana saja kapan saja dan tidak harus langsung bertemu media penyalur seperti menggunakan kertas ataupun media elektronik seperti laptop, tablet dan lainnya tapi juga bisa dilakukan didalam pikiran kita, seperti yang dijelaskan dalam buku "Menulis di Kala Covid-19“ oleh Abbas dan Erlyani (2020) bahwa ketika kita menggunakan pancaindra kita (mata, telinga, hidung, lidah dan kulit) hingga mengaktifkan pikiran kita itu artinya kita sedang menulis, dan menurut saya itu benar karena, kita membuat rencana terlebih dahulu didalam pikiran kita kemudian baru menuliskannya disebuah media. Abbas (2020) mengatakan menulis di otak adalah merekam segala informasi yang dipindai oleh pancaindra yang berlangsung selama kita hidup, dan karena itulah kita bisa membuat tulisan dalam pikiran kita karena selama kita hidup kita telah menemukan berbagai macam informasi.

Bagi saya menulis merupakan sesuatu yang menyenangkan, kenapa menyenangkan, karena menulis bagi saya adalah wadah untuk menuangkan perasaan yang sedang dirasakan, namun bagi saya menulis yang menyenangkan adalah ketika kita tidak merasa terbebani untuk menulis dan tidak membuat kita menjadi stres. Sebelumnya saya sempat menulis beberapa cerita namun tidak terselesaikan karena beberapa alasan, seperti saya merasa takut ketika cerita saya tidak bisa diterima oleh orang lain, atau jalan cerita saya tidak menarik untuk dibaca, akhirnya saya menghentikan menulis cerita tersebut tapi saya tetap menulis, menulis buku harian.

Saat ini sudah lama saya, kamu, dan kita semua tinggal di rumah, entah sudah berapa bulan lamanya karena adanya wabah korona atau Covid-19 yang sedang mampir di negara kita, Indonesia, oh korona berbaik hatilah untuk pergi dari tempat ini. Karena korona ini kita harus berdiam diri di rumah dan menghindari kerumunan orang-orang ataupun menghilangkan niatan 
untuk berkumpul bersama teman-teman, karena hal ini terkadang seseorang atau saya sendiri pun merasa bosan dan stres, belum lagi ditambah dengan tugas-tugas diperkuliahan atau tugas-tugas sekolah. Stres sendiri adalah perasaan yang dirasakan oleh seseorang saat menghadapi situasi yang tertekan (Ananda \& Apsari, 2020).

Stres yang dirasakan adalah karena merasa tertekan untuk selalu berada di rumah dan juga stres karena merasa takut ataupun cemas tentang kesehatan diri sendiri dan orang-orang diskeitar (WHO dalam Ananda \&Apsari, 2020). Menurut Cameron dan Meichenbaum dalam Ananda dan Apsari (2020) stres itu terbagi dalam beberapa bentuk tergantung ciri individu dalam mengalaminya dan kemampuan dalam menghadapinya (coping skill).

Saat saya merasa stres akan berbagai hal ditambah dengan kalimat "stay at home", saya akan mulai mendengarkan music atau menulis apapun itu untuk mengurangi perasaan stres saya, saya bisa menulis perasaan yang ingin saya ungkapkan ataupun hanya cerita mengapa saya menjadi stres atau menulis sebuah puisi yang entah itu bisa disebut puisi atau tidak tapi saya menyukainya dan menyimpannya untuk saya sendiri. Tindakan yang saya lakukan ketika merasa stres tersebut termasuk dalam tindakan escape avoidance yang artinya saya bereaksi dengan menghindar dari sumber stres atau masalah yang saya hadapi (Lazarus \& Folkman, 1984), saya meenghindari sumber stres saya dengan menulis ataupun dengan mendengarkan musik.

Saat menulis, tidak hanya menulis hal-hal yang terjadi dengan diri saya, menulis cerita yang belum pernah saya selesaikan, menulis tugas-tugas kuliah saya sering mengalami kesalahan pengetikan yang sering disebut anak gaul dengan istilah typo, oiya tidak hanya menulis di laptop tapi juga ketika menulis pesan diaplikasi chatting saya sering typo dan ketika menulis diatas kertas puln saya juga sering mengalami typo, menyedihkan? Tidak juga, kadang saya merasa lucu ketika melihat tulisan saya mengalami kesalahan pengetikkan dan hal itu membuat orangorang berpikir lebih untuk memahami tulisan saya, beruntungnya dalam hal berkirim pesan melalui hp saya mempunyai teman-teman yang mengerti akan hal tersebut dan tidak terlalu mempermasalahkan ketypo an yang saya lakukan, hanya saja saya sering merasa khawatir ketika saya mengerjakan tugas-tugas kampus dan saya juga telah berusaha lebih keras untuk tidak melakukan keasalahan dalam menulis tugas-tugas kuliah tapi terkadang hal itu tetap saja terjadi, sampai-samapi saya sering berkata dengan teman-teman saya, kalau saya ingin minum obat untuk menghilangkan typo jika obat itu ada. 
Dalam buku "Mudah menulis - menulis ala Ersis Writing Theory" dijelaskan bahwa memperbaiki typo dapat mengganggu kelancaran dalam menulis, bisa menyebabkan proses menyalin dari pikiran ke dalam tulisan digital akan berantakan, karena kerja otak yang cepat karena kerja otak yang cepat tersebut akan terhenti dikarenakan kita memperbaiki kesalahan dalam penulisan kata (typo) dan menurut saya itu memang benar adanya, karena kita membenarkan kesalahan penulisan tersebut bisa jadi tulisan yang sudah ada dalam pikiran kita menjadi hilang dan membuat kita harus mengingatnya kembali dan itu bisa menjadi berbeda dengan tulisan awal yang kita buat dipikiran kita.

Ketypoan tersebut tidak menyurutkan semangat saya untuk menulis, saya tetap menulis karena menulis menurut saya sangat menyenangkan dan dapat mengurangi perasaan stres yang saya alami selama masa pandemi ini, tidak hanya saat pandemi korona ini tapi saya juga sudah menulis sebelumnya. Menulis itu adalah sesuatu yang bisa dikatakan mudah menurut saya asal, kita tidak merasa terbebani atau tertekan dengan suatu hal ketika sedang menulis Warmansyah (2020) menulis itu mudah jikalau kita membuat mindset bahwa menulis itu adalah sutau hal yang mudah dan memberikan kemudahan bagi siapapun dan juga menurut Abbas (2015) dalam Menulis Menuliskan Diri tidak ada hal lain selain mindset kita yang membuat menulis itu adalah hal yang mudah dan menynangkan.

Selain menulis saya juga senang mendengarkan musik ketika saya merasa stres dan bosan, saat menulis saya juga sering sambil mendengarkan musik, saat mendengarkan musik saya bisa mendapat inspirasi untuk tulisan yang saya buat, atau sekedar menikmati musik itu saja untuk menenangkan diri dan menghilnagkan stres. Manfaat music dalam Asyari, Albari dan Uletika (2020) adalah untuk menenangkan jiwa dan juga dikatakan bahwa music menjadi salah satu solusi dalam mengurangi stres pada seseorang secara signifikan. Saputra (2020) menjelaskan bahwa mendengarkan selain dapat meredakan stres juga dapat meningkatkan fokus.

Musik-musik yang sering saya dengarkan lebih sering adalah musik dari negara Korea Selatan, ya, saya sangat suka musik yang dibawakan oleh penyanyi grup asal Korea Selatan, kenapa saya menyukainya karena menurut saya genre yang mereka miliki sangat cocok dengan saya dan music yang mereka miliki dapat saya nikmati dalam situasi apapun, semisal saya merasa sedih mereka memiliki jenis musik yang menenangkan, ketika saya merasa senang 
mereka juga memiliki jenis music yang bertema kebahagiaan yang meningkatkan rasa senang saya.

Penyanyi grup yang sukai bernama BTOB dibaca bi tu bi singkatan dari Born to Beat. BTOB merupakan boyband yang berasal dari Korea Selatan yang dibentuk oleh Cube Entertaiment, BTOB sendiri memiliki anggota sebanyak tujuh orang, salah satu anggota mereka berasal dari Chicago, Amerika Serikatdan yang lainnya merupakan warga Korea Selatan (Wikipedia.org), musik yang dibawakan oleh mereka sangat enak untuk didengar kalau bahasa gaulnya mah easy listening dan menurut saya setiap kalangan akan menyukai lagu-lagu mereka. Favorit saya adalah "It's Okay" karena lagu ini seperti memberi saya kekuatan ketika saya mengalami kesulitan dalam menghadapi suatu hal, memberikan saya semangat baru, bahwa apapun yang terjadi semuanya akan baik-baik saja, kamu sudah hebat kamu sudah berusaha keras dan jika lelah beristirahatlah tapi jangan pernah berhenti untuk berjuang dan bermimpi.

Karena menurut saya banyak kalangan anak remaja di Indonesia menyukai musik-musik dari Korea Selatan hal ini membuat segala yang berbau korea sangat banyak diminati oleh banyak orang baik dari segi musik, film, drama, cara berpakaian dan juga kosmetik, hal ini disebut sebagai fenomena demam Korean Wave. Robertson dalam Simbar (2016) mengatakan bahwa istilah Korean wave diberikan untuk adanya penyebaran atau geelombang Korea yang terjadi secara global diberbagai negara di dunia termasuk Indonesia. Terdapat beberapa dampak menurut Putri (2020) yang diakibatkan dari adanya Korean wave ini diantaranya menjadikan Korean sebagai inspirasi dalaam gaya berpakaaian, dapat memotivasi dan menjadi semaangat, bisa bersosialisasi dan mandiri, menghilangkan stres dan membuat diri merasa senang. Karena itulah ketika saya merasa stres saya akan mulai mendnegarkan lagu atau menulis karena menurut saya itu membantu saya menjadi sedikit tenang.

Live only once so make the best use of it. 화이팅... 


\section{DAFTAR PUSTAKA}

Abbas, E. W. (2015). Menulis Menuliskan Diri.

Abbas, E. W. (2020). Menulis di Otak dan Menuliskan Tulisan di Otak.

Abbas, E. W. (2020). Menulis Mudah, Menulis Ala Ersis Writing Theory.

Abbas, E. W., \& Erlyani, N. (2020). Menulis di Kala Badai Covid-19.

Ananda, S. S. D., \& Apsari, N. C. (2020). MENGATASI STRESS PADA REMAJA SAAT PANDEMI COVID-19 DENGAN TEKNIK SELF TALK. Prosiding Penelitian dan Pengabdian kepada Masyarakat, 7(2), 248-256.

Asyari, H., Albari, A. C., \& Uletika, N. S. (2020). Pemanfaatan Teknologi Virtual Reality dan Musik Sebagai Media untuk Mengurangi Stres pada Guru di SLBN Purbalingga. IENACO (Industrial Engineering National Conference) 82020.

https://id.wikipedia.org/wiki/BtoB

Lazarus, R.S \& Folkman, S. 1984. Stress appraisal and coping. Newyork : Springer Publishing Company.Inc.

Putri, L. A. (2020). Dampak Korea Wave Terhadap Prilaku Remaja Di Era Globalisasi. AlIttizaan: Jurnal Bimbingan Konseling Islam, 3(1), 42-48.

Saputra, M. B. G. (2020). Pengaruh Mendengarkan Musik Bagi Kenyamanan Pengendara Mobil Angkutan Umum di Gresik. Virtuoso (Jurnal Pengkajian dan Penciptaan Musik), 2(1), 47-55.

Simbar, F. K. (2016). Fenomena Konsumsi Budaya Korea Pada Anak Muda Di Kota Manado. HOLISTIK, Journal Of Social and Culture.

WARMANSYAH ABBAS, E. R. S. I. S. (2020). Menulis di Era Covid-19: Memanage Trauma Psikologis Menghindari Psikosomatis. Menulis di Era Covid-19: Memanage Trauma Psikologis Menghindari Psikosomatis. 